\title{
DFIG wind turbine under unbalanced power system conditions using adaptive fuzzy virtual inertia controller
}

\author{
Mohamed Zellagui ${ }^{1,2}$, \\ Heba Ahmed Hassan ${ }^{3}$, \\ Mohamed Nassim Kraimia ${ }^{4}$ \\ ${ }^{1}$ Department of Electrical Engineering, \\ Faculty of Technology, \\ University of Batna 2, Fesdis, Algeria \\ ${ }^{2}$ Department of Electrical Engineering, \\ École de Technologie Supérieure (ETS), \\ University of Québec, \\ Montréal, Canada \\ ${ }^{3}$ Department of Electrical Power Engineering, \\ Faculty of Engineering, \\ Cairo University, Giza, Egypt \\ ${ }^{4}$ Department of Electrical Engineering, \\ University of Sciences \& Technology \\ Houari Boumediene (USTHB), Algiers, Algeria \\ Email:m.zellagui@univ-batna2.dz, \\ mohamed.zellagui.1@ens.etsmtl.ca, \\ hebahassan@ieee.org, \\ nkraimia@usthb.dz
}

The Doubly-Fed Induction Generator (DFIG) based Wind Turbines Generator (WTG) with traditional Maximum Power Point Tracking (MPPT) control provides no inertia response under system frequency events. Recently, the DFIG wind turbines have been equipped with the Virtual Inertia Controller (VIC) to enhance the frequency stability of the power system. However, the conventional VICs with fixed gain have negative effects on the inter-area oscillations of regional networks. To cope with this drawback, this paper proposes a novel adaptive VIC to improve both the inter-area oscillations and frequency stability. In the proposed scheme, the gain of the VIC is dynamically adjusted using fuzzy logic. The effectiveness and control performance of the adaptive fuzzy VIC is evaluated under different frequency events such as loss of generation and three-phase fault with load shedding. The simulation studies are performed on a generic two-area network integrated with a DFIG wind farm, and the comparative results are presented for these three cases: DFIG without VIC, DFIG with fixed gain VIC, and DFIG with adaptive fuzzy VIC. The results confirm the ability of the proposed adaptive fuzzy VIC in improving both the interarea oscillations and frequency stability of the system.

Keywords: adaptive Virtual Inertia Controller (VIC), Doubly-Fed Induction Generator (DFIG), frequency stability, inter-area oscillations, Maximum Power Point Tracking (MPPT), Wind Turbine Generator (WTG)

\section{INTRODUCTION}

Frequency has always been an important index in power system operation, and an appropriate strategy should be adopted to maintain the necessary frequency control [1]. The highly fluctuating WTG and the presence of power electronic converters result in the reduction of the total system inertia which may have an effect on the frequency stability of the system. Therefore, it is becoming mandatory for the WTG to assist in the frequency regulation to improve the stability of power systems [2]. However, the DFIG with traditional MPPT control provides no 
inertial response during the system frequency events such as load shedding, loss of generation, and etc. [3].

The inertial response directly affects the initial rate of frequency deviation so that power systems with lower inertia are more prone to frequency instability [4]. Therefore, with increasing the penetration of the DFIG-based WTG, there are major concerns about the power system frequency stability [5]. A novel inertial emulation scheme proportion to the rate of change of frequency was presented [6]. Authors proposed a simplified model that accurately represents the behaviour of wind farms and its role in frequency control [7]. The nonlinear control tool, namely the input-to-state stability approach, was applied [8]. A variable droop gain scheme for a wind farm was proposed for frequency regulation [9]. An applied adaptive control with a torsional frequency updating mechanism was presented to counteract torsional damping deterioration and it was validated by simulations and real-time experiments [10].

Recently, the potential of a variable speed WTG for improving the system frequency stability has been addressed by a variety of VICs [11]. A first-order high-pass filter was used to activate the VIC only in the presence of significant frequency deviation [12]. On the other hand, research studies concluded that the reduced inertia of power systems due to the increased penetration of the DFIG improves the damping of power system oscillations [13]. In [14], authors used WTG and storage systems to improve the frequency control characteristics. Applied VIC optimisation control for frequency stability in the presence of different active power wind farm was introduced [15]. Authors in [16] proposed schemes to modulate the gains of inertia controller dynamically for a wide range of wind speeds. A novel integrated frequency governor, applied to the WTG, was proposed to provide fast active power support and scheduled power allocation [17, 18]. A proposed coordinated control of the DFIG for load frequency control problem was presented [19].

This paper presents a novel adaptive VIC to improve both the inter-area oscillations and frequency stability. In the proposed scheme, the gain of the VIC is dynamically adjusted using fuzzy logic under different frequency conditions such as loss of generation and three-phase fault with load shedding on a generic two-area power system integrated with a DFIG wind farm.

\section{DFIG WIND TURBINE WITH VIC}

\section{Model of DFIG wind turbine}

The general structure of a DFIG wind turbine together with its controllers is shown in Fig. 1. It consists of a turbine, drive-train, generator,

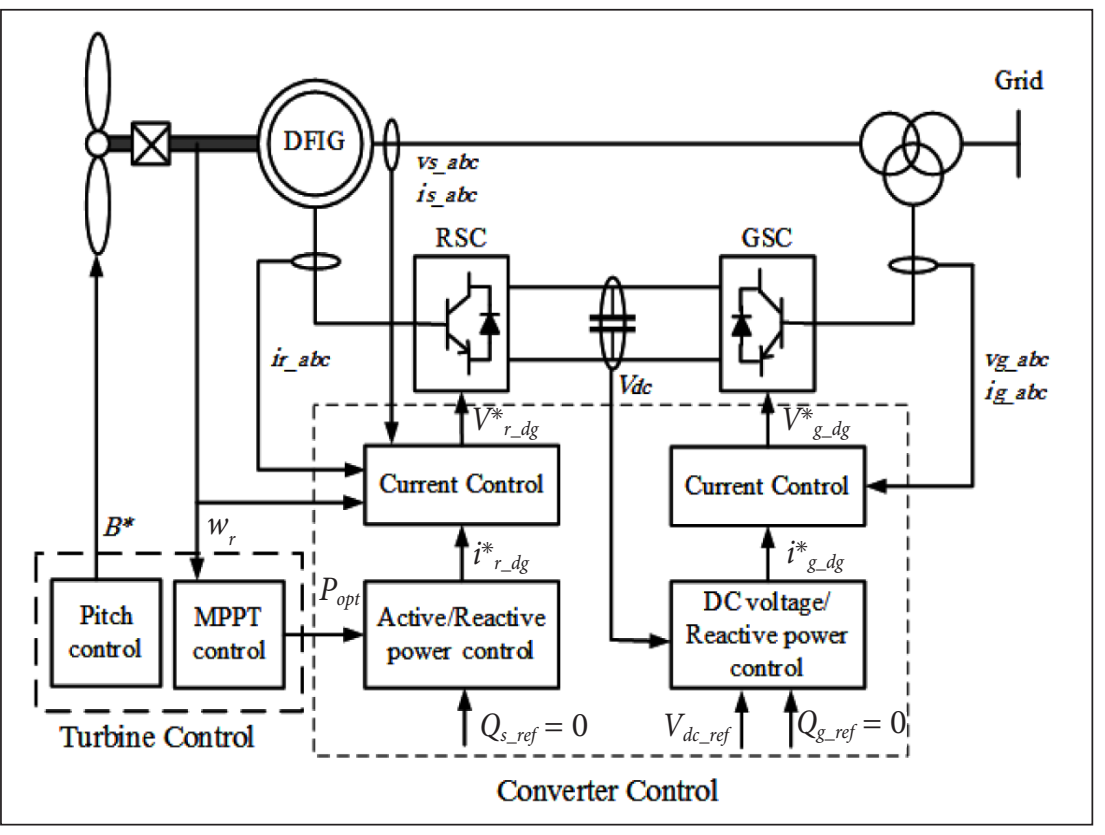

Fig. 1. DFIG wind turbine together with its controllers 
power electronic converters and control blocks. The turbine receives the kinetic energy of wind and delivers it in the form of rotating mechanical torque. Subsequently, the extracted mechanical torque is transmitted to the generator through a drive-train system. The generator is a wound rotor induction generator that both the stator and rotor are jointed to the grid.

In power system stability studies, very fast electric transients of the stator are usually disregarded and the system is modelled in the form of a voltage source behind transient impedance [14-19]. The model of mechanical and electrical systems is given as follows:

The mechanical system:

$$
\begin{aligned}
& 2 H_{t} \frac{d \omega_{t}}{d t}=T_{m}-k_{s h} \theta_{t w}-c_{s h} \frac{d \theta_{t w},}{d t}, \\
& \frac{1}{\omega_{e b}} \frac{d \theta_{t w}}{d t}=\omega_{t}-\omega_{r}, \\
& 2 H_{g} \frac{d \omega_{r}}{d t}=k_{s h} \theta_{t w}+c_{s h} \frac{d \theta_{t w}}{d t}-T_{e} .
\end{aligned}
$$

The electrical system:

$$
\begin{aligned}
& \frac{d E_{d}^{\prime}}{d t}=\omega_{e b}\left[\omega_{s} \frac{\left(L_{s}-L_{s}^{\prime}\right)}{T_{r}} i_{s q}+\right. \\
& \left.+\omega_{s}\left(\omega_{s}-\omega_{r}\right) E_{q}^{\prime}-\frac{E_{d}^{\prime}}{T_{r}}-\frac{\omega_{s} L_{m}}{L_{r}} v_{r q}\right], \\
& \frac{d E_{q}^{\prime}}{d t}=\omega_{e b}\left[-\omega_{s} \frac{\left(L_{s}-L_{s}^{\prime}\right)}{T_{r}} i_{s d}-\frac{E_{q}^{\prime}}{T_{r}}-\right. \\
& \left.-\omega_{s}\left(\omega_{s}-\omega_{r}\right) E_{d}^{\prime}-\frac{\omega_{s} L_{m}}{L_{r}} v_{r d}\right] .
\end{aligned}
$$

As illustrated in Fig. 1, in DFIGs, the rotor is jointed to the network through two backto-back power electronic converters. They are usually modelled in the form of PWM voltage source converters for injecting a controlled sinusoidal AC three phase voltage to the rotor windings. The converters should be able to work in both rectifier and inverter modes to provide bidirectional path for power flow between the rotor and network.

The Grid-Side Converter (GSC) is controlled to keep constant DC-link voltage and regulate the reactive power exchange between the converter and power grid. On the other hand, the Rotor-Side Converter (RSC) provides decoupled control of active and reactive powers of the generator [20].

The active power is conventionally controlled based on MPPT strategy, where the wind turbine can work at variable rotor speeds for extracting the maximum wind power, according to Fig. 2. In this strategy, if the wind speed exceeds a maximum allowable value, the pitch angle controller limits the output power. Furthermore, the reactive power can be independently controlled to support different grid requirements. However, due to a limited capacity of the converters and to provide a unity power factor, the reference of reactive power is usually set to zero [18].

\section{Model of Virtual Inertia Controller}

The DFIG with traditional MPPT control provides no inertial response to the network frequency events. Figure 3 shows a typical VIC for a DFIG wind turbine. It is a derivative controller

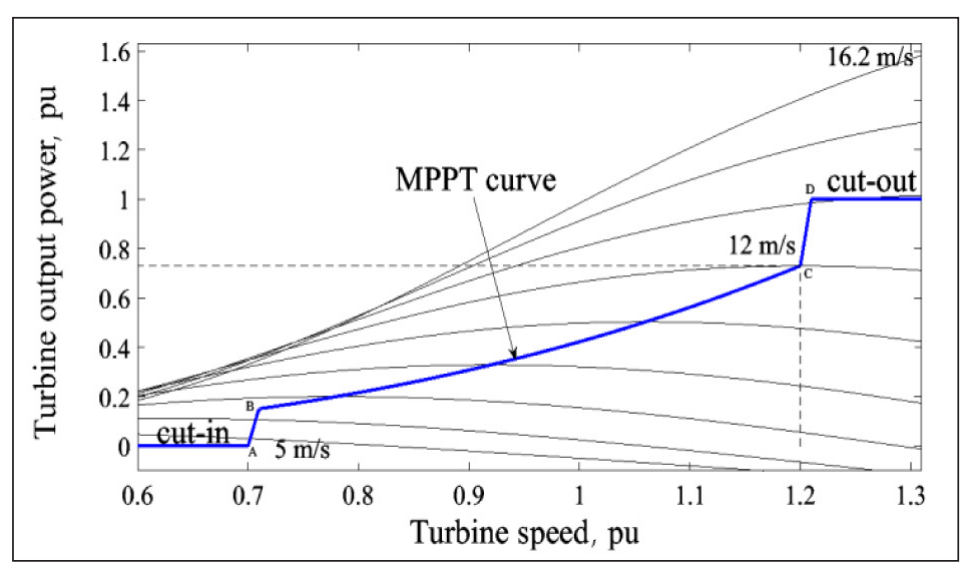

Fig. 2. MPPT curve of DFIG wind turbine 


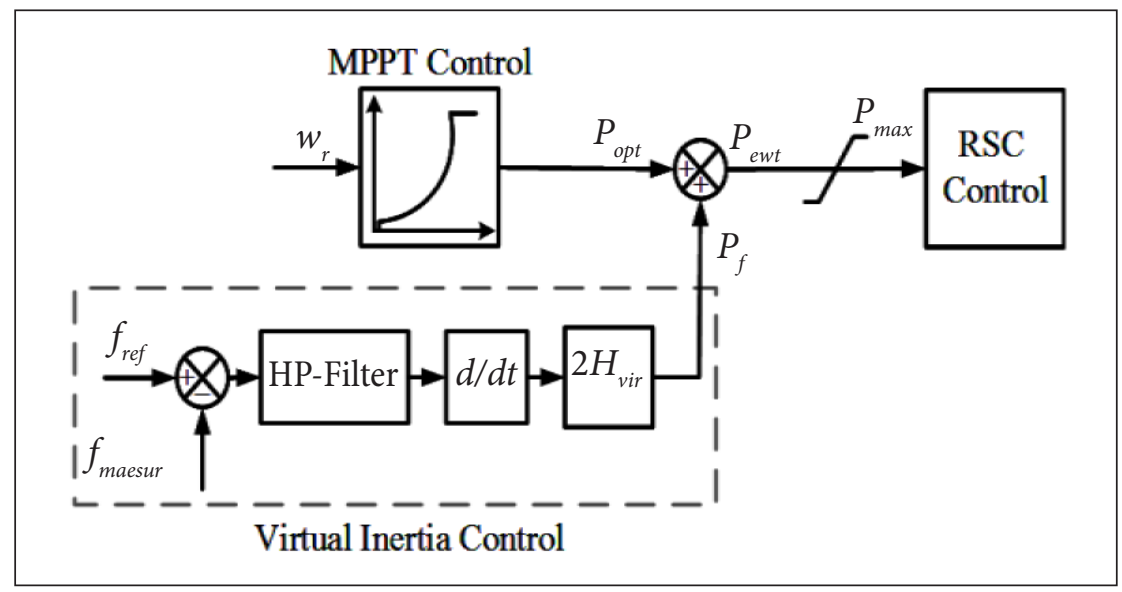

Fig. 3. DFIG active power control integrated with VIC

that provides a transient inertial response for the DFIG active power through the stored kinetic energy of the rotor.

The performance of the VIC is specified by the virtual inertia gain $\left(H_{v i r}\right)$. Moreover, a first-order high-pass filter is usually used to activate the controller only when there are significant frequency deviations. In this way, the DFIG's rotor motion equation can be expressed as follows [14-18]:

$$
\begin{aligned}
& P_{m_{w t}}-P_{e_{w t}}=2 H_{w t} \frac{d \omega_{r}}{d t}= \\
& =2 H_{w} \frac{d \omega_{r}}{d \omega_{s}} \times \frac{d \omega_{s}}{d t}=2 H_{v i r} \frac{d \omega_{s}}{d t},
\end{aligned}
$$

where $H_{v i r}$ takes the following form:

$$
H_{v i r}=H_{w t} \frac{d \omega_{r}}{d \omega_{s}} \cong H_{w t} \frac{\Delta \omega_{r}}{\Delta \omega_{s}}=H_{w t} \eta
$$

According to Equation (7), the virtual inertia directly depends on $\eta=\Delta \omega_{r} / \Delta \omega_{s}$ where $\Delta \omega_{\text {r }}$ and $\Delta \omega_{s}$ are the angular speed variations of the wind turbine and power system, respectively. As explained before, the DFIG has a wide range of speed regulation from $\omega_{r_{-} \text {cut-in }}$ to $\omega_{r_{-} \text {cut-off }}$ On the other hand, the traditional synchronous generators usually work quite close to the synchronous speed $\omega_{s}$ to keep the system frequency stability.

Therefore, considering that $\Delta \omega_{r}$ is much larger than $\Delta \omega_{s}$, and then $\eta \gg 1$, the increased penetration of DFIG wind farms provides a significant potential for network frequency regulation.

\section{COORDINATED DESIGN OF VIC AND INTER-AREA OSCILLATION DAMPING}

\section{Relationship between system inertia response and inter-area oscillations}

In this section, the dynamic equations of a typical regional power network are developed to analyse the relationship between the system inertia and inter-area oscillations. A two-area power network, as shown in Fig. 4, is considered, where $G_{1}$ and $G_{2}$ are the equivalent generators in the feeding side and receiving side, respectively.

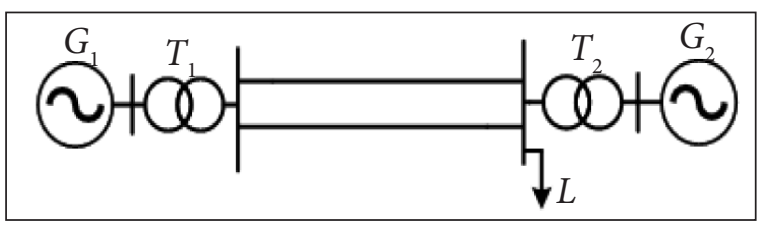

Fig. 4. Single line diagram of a two-area network

The swing equations of each generator are given by $[21,22]$ :

$$
\begin{aligned}
& 2 H_{i} \frac{d \omega_{i}}{d t}=P_{m_{i}}-P_{e_{i}}-D_{i}\left(\omega_{i}-1\right), \\
& \frac{d \delta_{i}}{d t}=\omega_{0}\left(\omega_{i}-1\right),
\end{aligned}
$$

where $I=1,2$ denotes the generator number.

In Equation (8), the electric output power of $G_{1}$ and $G_{2}$ can be calculated as follows [21]:

$$
P_{e_{1}}=E_{1}^{2} G_{11}+E_{1}^{\prime} E_{2}^{\prime}\left(G_{12} \cos \delta_{12}+B_{12} \sin \delta_{12}\right),
$$




$$
P_{e_{2}}=E_{2}^{2} G_{22}+E_{1}^{\prime} E_{2}^{\prime}\left(G_{12} \cos \delta_{12}-B_{12} \sin \delta_{12}\right)
$$

where $\delta_{12}=\delta_{1}-\delta_{2}$ is the power angle between the two networks, $G_{11}$ and $G_{22}$ are the equivalent internal conductance of $G_{1}$ and $G_{2}$, respectively, and $G_{12}$ and $B_{12}$ are the transfer conductance and susceptance between $G_{1}$ and $G_{2}$, respectively. Considering the mechanical power is constant and substituting by Equation (10) into Equation (8), the state equations of the system for a small perturbation around the operating point are obtained as follows [14-19], [23]:

$$
\begin{aligned}
& 2 H_{1} \frac{d \Delta \omega_{1}}{d t}=-K_{1} \Delta \delta_{12}-D_{1} \Delta \omega_{1}, \\
& 2 H_{2} \frac{d \Delta \omega_{2}}{d t}=-K_{2} \Delta \delta_{12}-D_{2} \Delta \omega_{2}, \\
& \frac{d \Delta \delta_{12}}{d t}=\omega_{0}\left(\Delta \omega_{1}-\Delta \omega_{2}\right),
\end{aligned}
$$

where:

$$
\begin{aligned}
& K_{1}=E_{1}^{\prime} E_{2}^{\prime}\left(-G_{12} \sin \delta_{12}+B_{12} \cos \delta_{12}\right), \\
& K_{2}=E_{1}^{\prime} E_{2}^{\prime}\left(-G_{12} \sin \delta_{12}-B_{12} \cos \delta_{12}\right),
\end{aligned}
$$

Based on Equations (10)-(14), the system dynamics depend on the inertia parameters. To evaluate the impacts of these parameters on the stability of inter-area oscillations, a reduced-order model based on the integral manifold theory can be used to integrate and eliminate unneeded differential equations. Accordingly, a reduced-order model of the system is derived as follows $[22,23]$ :

$$
\left|\begin{array}{l}
p \Delta \delta_{12} \\
p \Delta \omega_{12}
\end{array}\right|=\left|\begin{array}{cc}
-a_{1} \omega_{0} & \left(1-a_{2}\right) \omega_{0} \\
-K_{1} / 2 H_{1} & -D_{1} / 2 H_{1}
\end{array}\right| \mid \begin{gathered}
\Delta \delta_{12} \\
\Delta \omega_{12}
\end{gathered},
$$

where $\Delta \delta_{12}$ and $\Delta \omega_{12}$ are the states of the reduced-order model system, and respectively specify the rotor angle deviations and angular speed deviations between the two areas. $p$ is the derivative operator. From Equation (17), the system characteristic equation is obtained as follows:

$$
\begin{aligned}
& p^{2}+\left(a_{1} \omega_{0}+\frac{D_{1}}{2 H_{1}}\right) p+ \\
& +\frac{\omega_{0}}{2 H_{1}}\left[a_{1} D_{1}+\left(1-a_{2}\right) K_{1}\right]=0 .
\end{aligned}
$$

Subsequently, the system eigenvalues are given by:

$$
p_{1,2}=a \pm \beta i
$$

where the real part of the system eigenvalues is calculated as follows:

$$
\alpha=-\frac{1}{2}\left(a_{1} \omega_{0}+\frac{D_{1}}{2 H_{1}}\right)
$$

In general, the real parts of eigenvalues play a major role in the damping of system oscillations, such that if they become more negative, the damping will increase. According to Equation (20), in a regional power network, the eigenvalues real part $(\alpha)$ is inversely related to the inertia gain of the feeding side $\left(H_{1}\right)$. Consequently, it can be concluded that supporting more virtual inertia from a DFIG wind farm may increase the inter-area oscillations.

\section{Adaptive VIC for improving power system oscillations}

Although supporting more inertia by a DFIG can improve the frequency stability; however, the damping of inter-area oscillations will likely reduce. Therefore, a novel adaptive VIC for DFIG wind turbines is proposed to simultaneously handle both the inter-area oscillations and frequency stability.

The inter-area oscillations in a regional network can be specified by the angular speed deviations between the areas. For example, for the two-area system shown in Fig. 4, the inter-area oscillations are considered as $\Delta \omega_{12}=\Delta \omega_{1}-\Delta \omega_{2}$. This is a global signal that can be obtained using the wide-area measurements [24]. In the oscillatory conditions, one period of $\Delta \omega_{12}$ can be divided into four stages, as represented in Fig. 5.

In stages I and III, the amplitude of $\Delta \omega_{12}$ is increasing and a larger inertia can restrict it. On the other hand, in stages II and IV, the amplitude of $\Delta \omega_{12}$ is declining and a lower inertia will accelerate the oscillation damping. Thus, an adaptive VIC can help to damp the inter-area oscillations. Practically, the stages from I to IV can be recognized through the signals of $\Delta \omega_{12}$ and its derivative, as given in Table 1. 


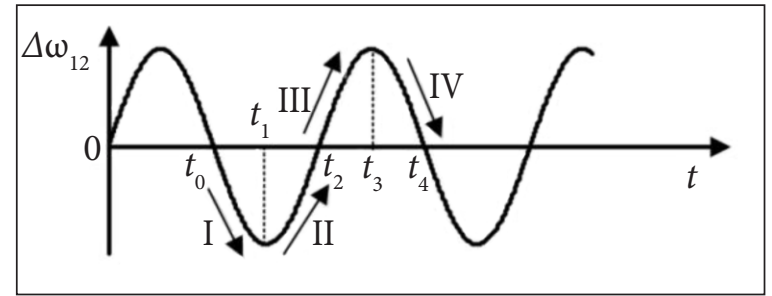

Fig. 5. Oscillation stages of $\Delta \omega_{12}$

Table 1. Adaptive inertia control for inter-area oscillation damping

\begin{tabular}{c|cccc}
\hline Stage & $\boldsymbol{\Delta} \boldsymbol{\omega}_{12}$ & $\boldsymbol{d}\left(\boldsymbol{\Delta} \boldsymbol{\omega}_{\mathbf{1 2}}\right) / \boldsymbol{d} \boldsymbol{t}$ & $\boldsymbol{H}_{\text {vir }}$ \\
\hline I & Negative & Negative & High \\
\hline II & Negative & Positive & Low \\
\hline III & Positive & Positive & High \\
\hline IV & Positive & Negative & Low \\
\hline
\end{tabular}

\section{Designing the adaptive VIC using fuzzy logic method}

Fuzzy logic is the most appropriate approach to be used when implementing controllers with inexact inputs and linguistic control patterns. The fuzzy logic controllers do not require an accurate mathematical model of the system, and the design criteria are linguistic rules. The fuzzy rules are universally determined based on human experience from the desirable control actions. They can also provide robust performance under nonlinear circumstances $[25,26]$.
In this section, an adaptive VIC is designed for DFIG wind turbines using the fuzzy logic method. The proposed fuzzy VIC can help to damp the interarea oscillations in regional power networks previously presented. Figure 6 represents the block diagram of the DFIG's active power controller integrated with the proposed fuzzy VIC. In this scheme, the virtual inertia gain $\left(H_{v i r}\right)$ is adaptively regulated with respect to the angular speed deviations between two areas $\left(\Delta \omega_{12}\right)$ and its change rate $\left(d \Delta \omega_{12} / d t\right)$.

Every fuzzy controller consists of three parts called as fuzzification, fuzzy inference mechanism, and defuzzification [25-27]. Fuzzification is the procedure of converting the crisp input variables into the corresponding fuzzy values. The Membership Functions (MFs) determine the degree of belonging of the input variables to one of the fuzzy sets. Here, two MFs (i.e. Negative and Positive) are employed to fuzzify each of the two input variables, according to Fig. 7a and $b$, respectively. In the next step, the fuzzy inference system deduces the fuzzy output based on the available fuzzy rules. The implication of fuzzy rules requires a sufficient knowledge and experience about the practical system.

They are expressed by a set of linguistic statements linking a limited number of conditions with a limited number of consequences. In this study, the appropriate control actions are obtained using the fact that the high inertia is needed

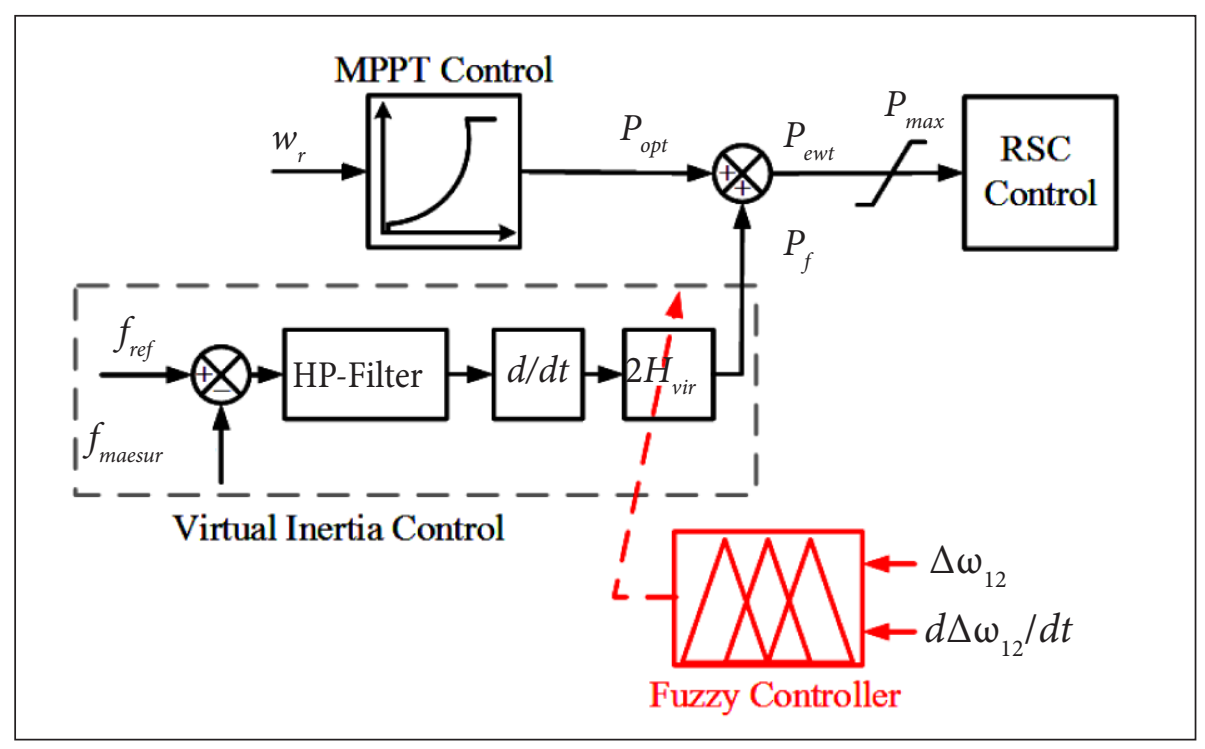

Fig. 6. Schematic of the proposed fuzzy adaptive VIC 


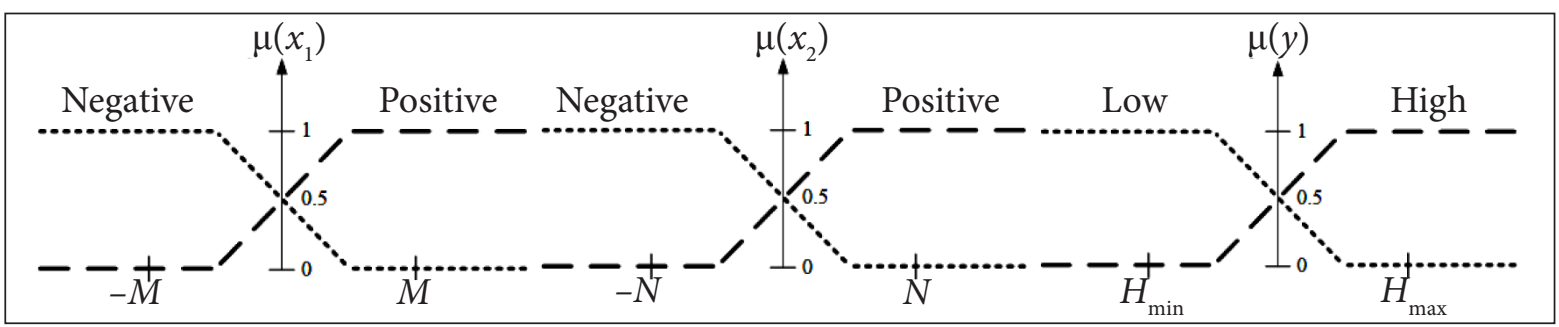

Fig. 7. Input and output fuzzy MFs: (a) $X_{1}=\Delta \omega_{12^{\prime}}$ (b) $X_{2}=d\left(\Delta \omega_{12}\right) / d t$, (c) $y=H_{\text {vir }}$

when the inter-area oscillations are increasing, and the low inertia adjustments require when the oscillations are approaching to the steady state values.

Accordingly, two MFs are considered for the fuzzy output as "High" or "Low", which are presented in Fig. 7c. The fuzzy inference system used is the Mamdani type and the Max-Min method to deduce the fuzzy output [27]. In addition, four fuzzy rules are applied as follows:

Rule (1): IF ( $\Delta \omega_{12}$ is "Negative") AND ( $d \Delta \omega_{12} /$ $d t$ is "Negative") THEN ( $H_{v i r}$ is "High"),

Rule (2): IF ( $\Delta \omega_{12}$ is "Negative") AND ( $d \Delta \omega_{12} /$ $d t$ is "Positive") THEN ( $H_{v i r}$ is "Low"),

Rule (3): IF ( $\Delta \omega_{12}$ is "Positive") AND ( $d \Delta \omega_{12} /$ $d t$ is "Positive") THEN ( $H_{v i r}$ is "High"),

Rule (4): IF ( $\Delta \omega_{12}$ is "Positive") AND ( $d \Delta \omega_{12} /$ $d t$ is "Negative") THEN ( $H_{v i r}$ is "Low").

Finally, the centroid defuzzifer is used to convert the fuzzy output into the corresponding crisp output signal [27]. For optimal design of the fuzzy controller, the parameters of the inputs and output MFs $\left(M, N, H_{\text {min }}, H_{\max }\right)$ are determined through Genetic Algorithm (GA) [28, 29]. To do so, the Integral Time-weighted Absolute Error (ITAE) is considered as the performance index [30] and it is defined as follows:

$$
\operatorname{ITAE}=\int_{0}^{\infty}\left|\Delta \omega_{12}(t)\right| t d t .
$$

The ITAE integrates the absolute error multiplied by the time over time. The ITAE has the best selectivity considering that the oscillations settle much more quickly than the other tuning methods such as the Integral Squared Error (ISE) and Integral Absolute Error (IAE) [30].

\section{CASE STUDY AND SIMULATION STUDIES}

In this section, the dynamic performance of the proposed fuzzy adaptive VIC is evaluated using simulation studies. The test system is a generic twoarea power network, as presented in Fig. $8[12,21]$.

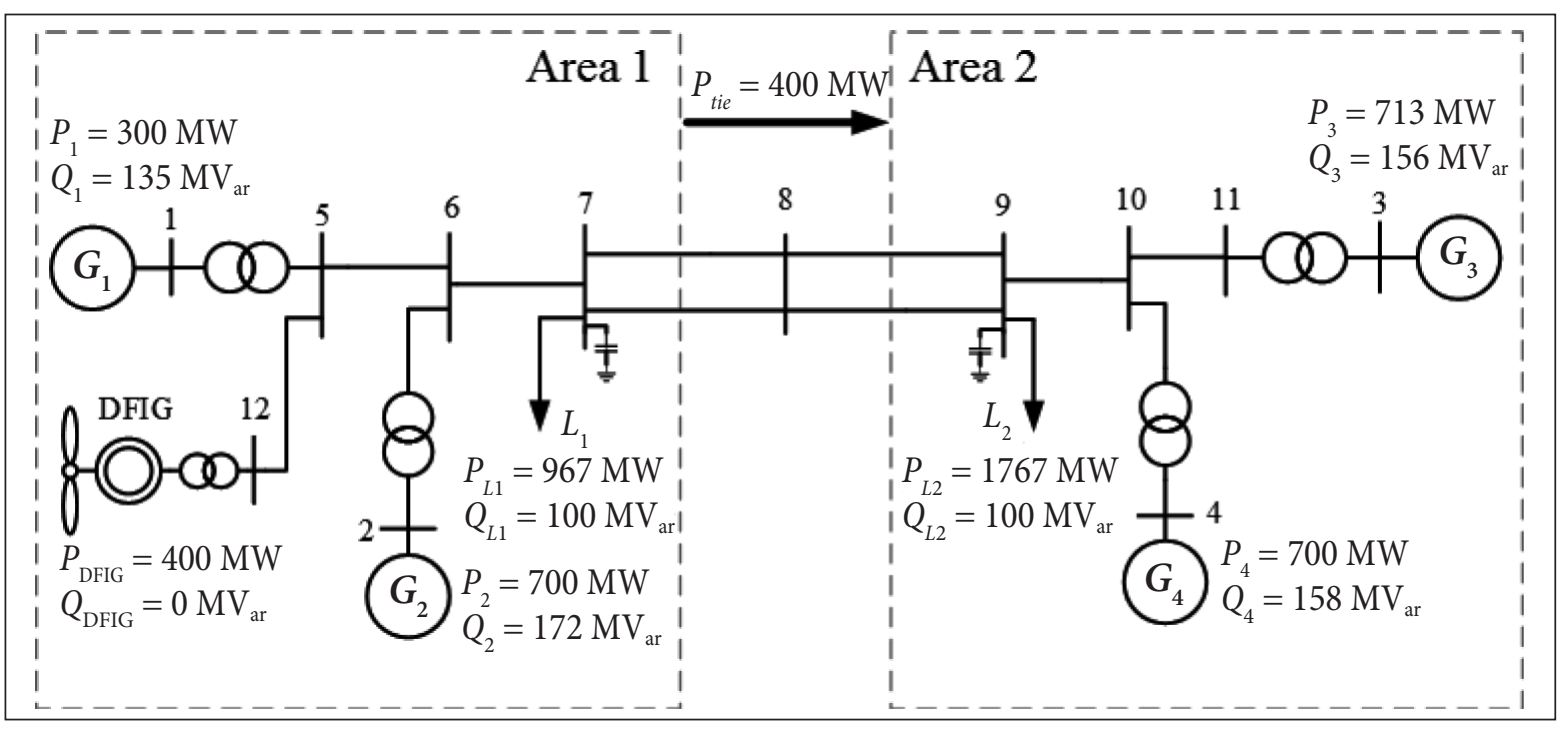

Fig. 8. The test system 
Area 1 contains two conventional synchronous generators $\left(G_{1}\right.$ and $\left.G_{2}\right)$, one aggregated load $\left(L_{1}\right)$ and one DFIG wind farm. Area 2 also includes two conventional synchronous generators $\left(G_{3}\right.$ and $\left.G_{4}\right)$ and one aggregated load $\left(L_{2}\right)$.

The nominal capacity of the generation units and loads are shown in Fig. 8. As marked in the figure, Area 1 nominally sends about $400 \mathrm{MW}$ to Area 2 via the power tie-lines. The wind farm was modelled as a single equivalent wind turbine with a capacity of $400 \mathrm{MW}$ ( 80 units of $5 \mathrm{MW}$ ) and unity power factor. Although the wind farm practically includes a large number of wind turbines, considering each individual wind turbine in the modelling process raises the complexity and simulation time. To overcome this problem, the aggregation method is used in this paper [19]. In the following, the modal analysis results and the time domain transient responses are presented as comparative studies between the three following cases:

- Case 1: DFIG without VIC,

- Case 2: DFIG with fixed gain VIC,

- Case 3: DFIG with fuzzy adaptive VIC.

\section{Modal analysis}

The test system was simulated using MATLAB/ Simulink software package, and its linear statespace model was extracted. Based on that, Table 2 lists the electromechanical oscillatory modes of the system. Modes 1 and 2, respectively, represent the local oscillatory modes of the areas 1 and 2, while mode 3 is associated with the inter-area oscillations. This paper intends to focus on the inter-area oscillatory mode of the system with frequency $0.4391 \mathrm{~Hz}$ and damping ratio $3.15 \%$. With this regard, Table 3 implies the normalized participation factor of each synchronous generator in the inter-area oscillatory mode. $G_{1}$ and $G_{3}$ are shown to have the highest participation factor in the inter-area oscillations.
Table 3. Normalized participation factor in inter-area oscillations

\begin{tabular}{c|c|c|c|c}
\hline Generator & $\mathbf{G}_{\mathbf{1}}$ & $\mathbf{G}_{\mathbf{2}}$ & $\mathbf{G}_{\mathbf{3}}$ & $\mathbf{G}_{\mathbf{4}}$ \\
\hline Participation factor & 0.66 & 0 & 1 & 0.09 \\
\hline
\end{tabular}

Table 4 compares the inter-area oscillatory modes of the test system when the DFIG operates with different inertia control strategy. It is observed that the DFIG equipped with the fixed gain VIC decreases the damping ratio from 3.15 to $2.54 \%$, while the proposed adaptive VIC increases it to $10.42 \%$. However, in each of the three cases, there is no considerable change in the oscillation frequency.

Table 4. Inter-area oscillatory modes for different virtual inertia control strategy

\begin{tabular}{cc|c|c}
\hline & Eigenvalue & $\begin{array}{c}\text { Frequency } \\
(\mathrm{Hz})\end{array}$ & $\begin{array}{c}\text { Damping } \\
\text { ratio (\%) }\end{array}$ \\
\hline Case 1 & $-0.0870 \pm 2.7591 i$ & 0.4391 & 3.15 \\
\hline Case 2 & $-0.0693 \pm 2.7168 i$ & 0.4324 & 2.54 \\
\hline Case 3 & $-0.2742 \pm 2.6175 i$ & 0.4166 & 10.42 \\
\hline
\end{tabular}

To compare the system transient behaviours with the three cases 1,2 and 3, the results of time domain simulations are presented for different frequency events such as sudden loss of generation and three-phase fault with load shedding.

Transient behaviours under loss of generation In this first test case, a sudden loss of generation by $250 \mathrm{MW}$ of $G_{2}$ is considered to occur. Following this event, the system frequency experiences a temporary fall. The minimum frequency directly affects the system frequency stability during the transient process. According to Fig. 9a, the minimum frequency of the system increases when the DFIG wind farm operates in cases 2 and 3. Therefore, both cases 2 and 3 can offer better frequency stability compared to case 1 .

Table 2. Electromechanical oscillatory modes

\begin{tabular}{c|c|c|c|c}
\hline Mode No. & Eigenvalue & Frequency $(\mathrm{Hz})$ & Damping ratio (\%) & Oscillation mode \\
\hline 1 & $-0.6217 \pm 6.5097 i$ & 1.0360 & 9.51 & Local (\#1) \\
\hline 2 & $-0.6539 \pm 7.2618 i$ & 1.1557 & 8.97 & Local (\#2) \\
\hline 3 & $-0.0870 \pm 2.7591 i$ & 0.4391 & 3.15 & Inter-area \\
\hline
\end{tabular}



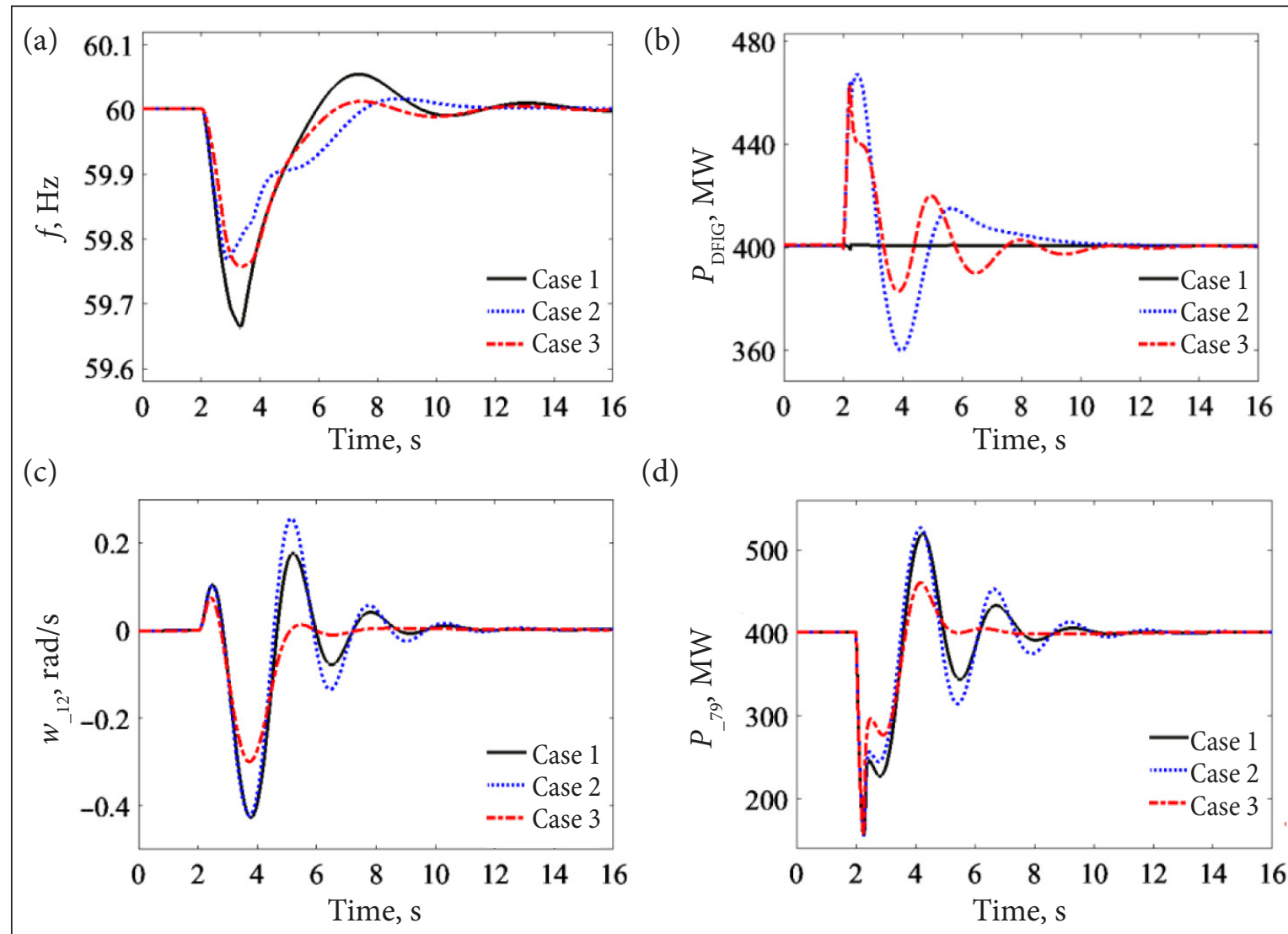

(d)

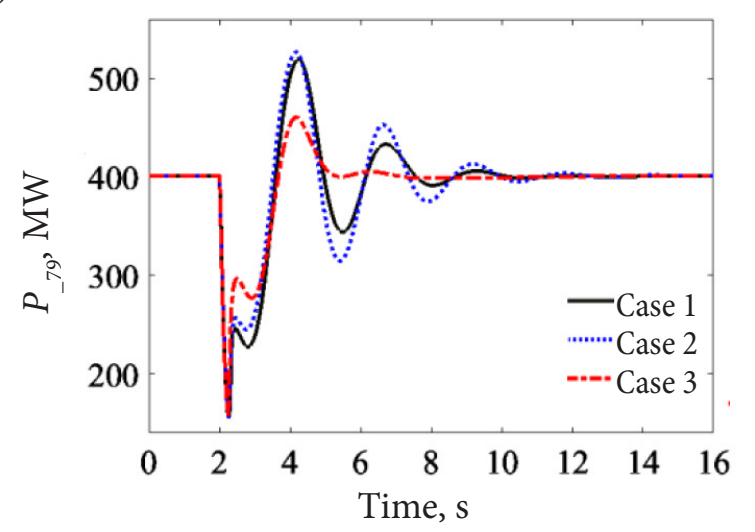

Fig. 9. Transient behaviours under sudden loss of generation: (a) network frequency, (b) DFIG active power, (c) angular speed deviation between $G_{1}$ and $G_{3^{\prime}}(d)$ inter-area power oscillation

This is due to the inertial response of DFIG active power, as shown in Fig. 9b. It is observed that in cases 2 and 3, the DFIG active power changes dynamically to support the system frequency, while it stays almost constant in case 1 .

Figures $9 \mathrm{c}$ and $\mathrm{d}$, respectively, represent the oscillations between two sub-regional networks in terms of the angular speed deviation between $G_{1}$ and $G_{3}\left(\Delta \omega_{12}\right)$ and the active power passing through the tie-lines between the buses 7 and $9\left(P_{79}\right)$. It is worth noting that $G_{1}$ and $G_{3}$ are the generators with the highest participation in the inter-area oscillation mode, as previously indicated in Table 3. The figures reveal that both the amplitude and time of oscillations are increased in case 2, while they are effectively suppressed in case 3 . This is achieved by the adaptive control performance of the proposed VIC with respect to the inter-area oscillations, as shown in Fig. 9d. While in case 2, the DFIG supports the fixed virtual inertial response during the frequency event.
To provide a quantitative comparison between the three cases, Table 5 compares the minimum network frequency $\left(f_{\min }\right)$, the maximum absolute deviation of $\Delta \omega_{12}\left(\max \left|\Delta \omega_{12}\right|\right)$ and its settling time $(\Delta t)$. Table 5 indicates that the minimum frequency in case 1 is $59.65 \mathrm{~Hz}$, while it increases to 59.77 and 59.76 in cases 2 and 3 , respectively. On the other hand, the adaptive fuzzy VIC decreases the $\max \left|\Delta \omega_{12}\right|$ and $\Delta t_{s}$ by $29 \%$ and $54 \%$ relative to case 1 , respectively. However, the fixed gain VIC increases them from 0.425 to $0.428(\mathrm{rad} / \mathrm{s})$ and 6.38 to $7.22(\mathrm{~s})$, respectively.

Table 5. The quantitative comparison under loss of generation

\begin{tabular}{c|ccc}
\hline & $\boldsymbol{f}_{\text {min }}(\mathbf{H z})$ & $\left|\boldsymbol{\Delta}_{\mathbf{1 2}}\right|(\mathbf{r a d} / \mathbf{s})$ & $\boldsymbol{\Delta t}_{\boldsymbol{s}}(\mathbf{s e c})$ \\
\hline Case 1 & 59.65 & 0.425 & 6.38 \\
\hline Case 2 & 59.77 & 0.428 & 7.22 \\
\hline Case 3 & 59.76 & 0.301 & 2.92 \\
\hline
\end{tabular}


Transient behaviours under three-phase fault with load shedding

In the second test case, a three-phase to ground fault is considered to occur in the middle of one of the tie-lines at $t=2 \mathrm{sec}$ and to be cleared after $100 \mathrm{~m} \mathrm{sec}$ by opening the circuit breakers at the two ends of the faulty line. Then, $200 \mathrm{MW}$ load shedding of $L_{2}$ will be immediately imposed to avoid overloading of the healthy line. Under these circumstances, breaking the tie-line between two networks results in the inter-area oscillations, and the load shedding increases the system frequency.

Figures $10 \mathrm{a}-\mathrm{d}$ represent the transient behaviours of the system in terms of the system frequency $(f)$, the DFIG active power $\left(P_{-D F I G}\right)$, the angular speed deviation between $G_{1}$ and $G_{3}\left(\Delta \omega_{12}\right)$, and the active power of tie-lines between buses 7 and $9\left(P_{79}\right)$, respectively. As shown in Fig. 10a, both the fixed and adaptive VICs are successful to restrict the maximum frequency and its change rate. On the other hand, Fig. $10 \mathrm{c}$ and $\mathrm{d}$ reveal that the use of the proposed adaptive VIC can dramatically reduce the system inter-area oscillations, while the fixed gain VIC increases them for both of the amplitude and time of oscillations.

Table 6 provides the quantified comparative results between the three cases studies. The maximum frequency decreases from $60.69 \mathrm{~Hz}$ in case 1 to 60.43 and $60.38 \mathrm{~Hz}$ in cases 2 and 3, respectively. The maximum absolute deviation of $\Delta \omega_{12}$ in case 3 is decreased by about $22 \%$ relative to case 1 . In case 3 , the settling time of inter-area oscillations decreases by $43 \%$ relative to case 1 , while it increases by $10 \%$ in case 2 .

Table 6. The quantitative comparison under three-phase fault with load shedding

\begin{tabular}{ccccc}
\hline & $\boldsymbol{f}_{\min }(\mathbf{H z})$ & $\left|\boldsymbol{\Delta} \boldsymbol{\omega}_{\mathbf{1 2}}\right|(\mathbf{r a d} / \mathbf{s})$ & $\boldsymbol{\Delta t}_{\mathbf{s}}(\mathbf{s e c})$ \\
\hline Case 1 & 60.69 & 0.60 & 8.53 \\
\hline Case 2 & 60.43 & 0.58 & 9.39 \\
\hline Case 3 & 60.38 & 0.47 & 4.80 \\
\hline
\end{tabular}

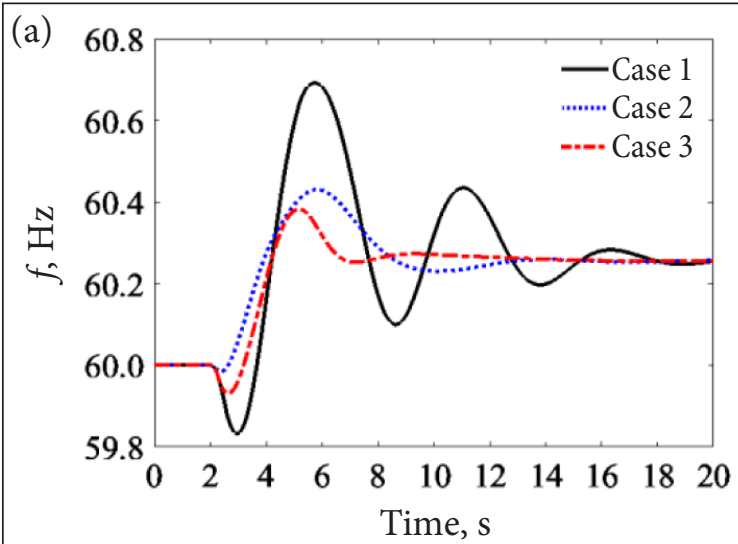

(c)

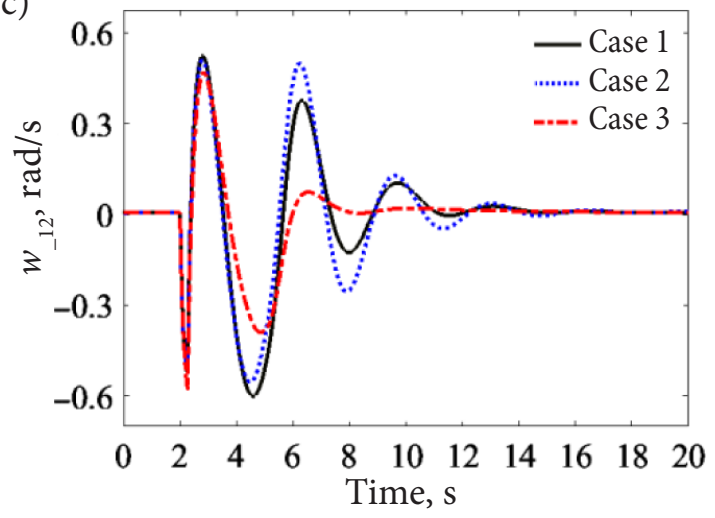

(b)

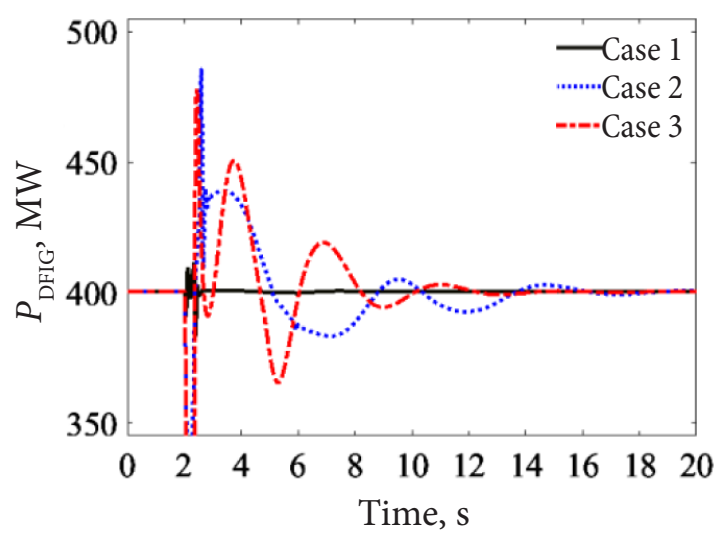

(d)

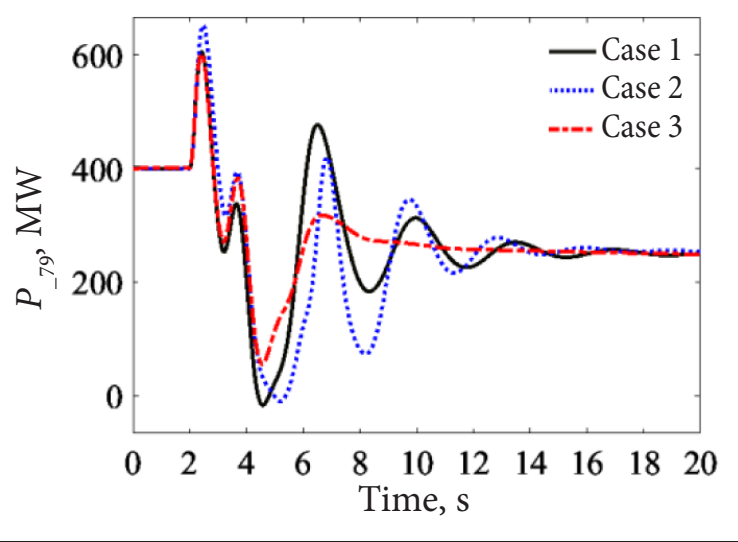

Fig. 10. Transient behaviours under three-phase fault with load shedding: (a) network frequency, (b) DFIG active power, (c) angular speed deviation between $G_{1}$ and $G_{3^{\prime}}(d)$ inter-area power oscillation 


\section{CONCLUSIONS}

This paper revealed that the increased penetration of DFIG wind farms, which are equipped with a traditional fixed gain VIC, may increase the inter-area oscillations of regional power networks. In order to solve this problem, a novel adaptive VIC was proposed in this paper, where the virtual inertia gain $\left(H_{v i r}\right)$ was not kept fixed but dynamically adjusted using fuzzy logic with respect to inter-area oscillations.

The effectiveness of the proposed adaptive fuzzy VIC was verified through simulation studies for the system under different operating conditions, such as loss of generation and three-phase fault with load shedding. The obtained results confirm that the DFIG equipped with the proposed adaptive fuzzy VIC can provide a better performance than the traditional fixed gain VIC in terms of improving the damping of the inter-area oscillations and frequency stability.

To further extend this research work, authors are planning to study other large power systems in the presence of hybrid renewable energy resources. There are also plans to apply novel optimisation algorithms to calculate the parameters of controllers in order to enhance the frequency stability of power systems.

Received 15 February 2019 Accepted 29 March 2019

\section{NOMENCLATURE} tants

$H_{t}, H_{g}-$ Turbine and generator inertia cons-

$\omega_{t}, \omega_{r}-$ Turbine and generator angular speeds

$c_{s h}, k_{s h}, \theta_{t w}$ - Damping, stiffness and twist angle of shaft

$\omega_{e b}, \omega_{s}$ - Electrical base and synchronous speeds

$T_{m}, T_{e}$ - Mechanical and electrical torques

$i_{s d}, i_{s q}-d$ and $q$ axis stator currents

$v_{r d}, v_{r q}-d$ and $q$ axis rotor voltages

$E_{d}^{r d}, E_{q}^{r q}, d$ and $q$ axis voltages behind transient reactance

$R_{s}, R_{r}$ - Stator and rotor resistances

$L_{s}, L_{r}, L_{m}$ - Stator, rotor and mutual inductances

$L_{s}$ - Stator transient inductance

$T_{r}=L_{r} / R_{r}-$ Rotor time constant

$P_{m}, P_{e}-$ Mechanical and electrical powers $\omega, \delta$ - Rotor angular speed and position

$f_{\text {min }}$ - Minimum frequency

$\omega_{0}$ - Rated angular speed of power system

$H, D$ - Inertia and damping coefficients

$H_{v i r}$ - Virtual inertia gain

$P, Q-$ Active and reactive powers

$\delta_{12}$ - Power angle between two networks

\section{References}

1. Fu Y., Zhang X., Hei Y., Wang H. Active participation of variable speed wind turbine in inertial and primary frequency regulations. Electric Power Systems Research. 2017. Vol. 147. P. 174-184.

2. Pradhan C., Bhende C. N., Samanta A. K. Adaptive virtual inertia-based frequency regulation in wind power systems. Renewable Energy. 2018. Vol. 115. P. 558-574.

3. Kayikçi M., Jovica V. M. Dynamic contribution of DFIG-based wind plants to system frequency disturbances. IEEE Transactions on Power Systems. 2009. Vol. 24. No. 2. P. 859-867.

4. Gautam D., Goel L., Ayyanar R., Vittal V., Harbour T. Control strategy to mitigate the impact of reduced inertia due to doubly fed induction generators on large power systems. IEEE Transactions on Power Systems. 2011. Vol. 26. No. 1. P. 214-224.

5. Ochoa D., Sergio M. Fast-frequency response provided by DFIG-wind turbines and its impact on the grid. IEEE Transactions on Power Systems. 2017. Vol. 32. No. 5. P. 4002-4011.

6. Bhatt P., Long C., Wu J., Mehta B. Dynamic participation of DFIG for frequency regulation in electrical power systems. Energy Procedia. 2017. Vol. 142. P. 2183-2188.

7. Varzaneh S. G., Abedi M., Gharehpetian G. B. A new simplified model for assessment of power variation of DFIG-based wind farm participating in frequency control system. Electric Power Systems Research. 2017. Vol. 148. P. 220-229.

8. Toulabi M., Bahrami S., Ranjbar A. M. An inputto-state stability approach to inertial frequency response analysis of doubly-fed induction generator-based wind turbines. IEEE Transactions on Energy Conversion. 2017. Vol. 32. No. 4. P. 14181431.

9. Li Y., Xu Z., Zhang J., Wong K. P. Variable gain control scheme of DFIG based wind farm for 
over-frequency support. Renewable Energy. 2018. Vol. 120. P. 379-391.

10. Xi X., Geng H., Yang G., Li S., Gao F. Torsional oscillation damping control for DFIG based wind farm participating in power system frequency regulation. IEEE Transactions on Industry Applications. 2018. Vol. 54. No. 4. P. 3687-3701.

11. Dreidy M., Mokhlis H., Mekhilef S. Inertia response and frequency control techniques for renewable energy sources: A review. Renewable and Sustainable Energy Reviews. 2017. Vol. 69. P. 144-155.

12. Zhang Z. S., Sun Y. Z., Lin J., Li G. J. Coordinated frequency regulation by doubly fed induction generator-based wind power plants. IET Renewable Power Generation. 2012. Vol. 6. No. 1. P. 38-47.

13. Zhang X., Fu Y., Wang S., Wang Y. Effects of two-area variable inertia on transient stabilisation in interconnected power system with DFIG-based wind turbines. IET Renewable Power Generation. 2017. Vol. 11. No. 5. P. 696-706.

14. Zhao H., Wu Q., Guo Q., Sun H., Xue Y. Optimal active power control of a wind farm equipped with energy storage system based on distributed model predictive control. IET Generation, Transmission \& Distribution. 2016. Vol. 10. No. 3. P. 669-677.

15. Tian X., Wang W., Chi Y., Li Y., Liu C. Virtual inertia optimisation control of DFIG and assessment of equivalent inertia time constant of power grid. IET Renewable Power Generation. 2018. Vol. 12. No. 15. P. 1733-1740.

16. Pradhan C., Bhende C. N., Samanta A. K. Adaptive virtual inertia-based frequency regulation in wind power systems. Renewable Energy. 2018. Vol. 115. P. 558-574.

17. Fu Y., Zhang X., Hei Y., Wang H. Active participation of variable speed wind turbine in inertial and primary frequency regulations. Electric Power Systems Research. 2017. Vol. 147. P. 174-184.

18. Fu Y., Zhang H., Mi Y., Huang L., Li Z., Wang J. Control strategy of DFIG in hybrid micro-grid using sliding mode frequency controller and observer. IET Generation, Transmission \& Distribution. 2018. Vol. 12. No. 11. P. 2662-2669.

19. Sonkar P., Rahi O. P. Load frequency control of multi-area interconnected system comprising DFIG-based wind turbine equipped with coor- dinated control. Iranian Journal of Science and Technology, Transactions of Electrical Engineering. 2018. Vol. 42. No. 1. P. 1-20.

20. Wu F., Zhang X. P., Godfrey K., Ju P. Small signal stability analysis and optimal control of a wind turbine with doubly fed induction generator. IET Generation, Transmission \& Distribution. 2007. Vol. 1. No. 5. P. 751-760.

21. Kundur P. Power System Stability and Control. First edition. New York, USA: McGraw-Hill Education, 1994.

22. Machowski J., Bialek J. W., Bumby J. R. Power System Dynamics: Stability and Control. Second edition. USA: Wiley, 2008.

23. Xiangyi C., Chunyan L., Yunli W. Analysis of the inter-area low frequency oscillations in large scale power systems, 6th IEEE Conference on Industrial Electronics and Applications. Beijing, China, 21-23 June 2011.

24. Asgharia R., Mozafari S. B., Amraeeb T. Delay-scheduled controllers for inter-area oscillations considering time delays. International Journal of Engineering, Transactions B: Applications. 2018. Vol. 31. No. 11. P. 1852-1861.

25. Zadeh L. A. Fuzzy sets, fuzzy logic, and fuzzy systems. In: Advances in Fuzzy Systems - Applications and Theory. USA: World Scientific Publishing, 1996.

26. Aliev R. A., Zadeh L. A. Fuzzy Logic Theory and Applications: Part I and Part II. USA: World Scientific Publishing, 2018.

27. Momoh J. A., Maand X. W., Tomsovic K. Overview and literature survey of fuzzy set theory in power systems. IEEE Transactions on Power Systems. 1995. Vol. 10. No. 3. P. 1676-1690.

28. Affenzeller M., Wagner S., Winkler S., Beham A. Genetic Algorithms and Genetic Programming: Modern Concepts and Practical Applications. UK: CRC Press, 2009.

29. Dawid H. Adaptive Learning by Genetic Algorithms: Analytical Results and Applications to Economical Models. Germany: Springer-Verlag Berlin Heidelberg, 1999.

30. Pal B., Chaudhuri B. Robust Control in Power Systems. Series: Power Electronics and Power Systems. USA: Springer, 2005. 
Mohamed Zellagui, Heba Ahmed Hassan, Mohamed Nassim Kraimia

DVIGUBO MAITINIMO INDUKCINIU

GENERATORIUMI PAREMTA VĖJO

TURBINA NESUBALANSUOTOS APKROVOS

ENERGETIKOS SISTEMOJE NAUDOJANTI

ADAPTYVŲ NERAIŠKŲ VIRTUALŲ INERCIJOS

\section{VALDIKLI}

Santrauka

Dvigubo maitinimo indukciniu generatoriumi paremtas vejo turbinos generatorius su tradiciniu maksimalios galios taško stebejjimo valdymu nesuteikia inercijos atsako esant sistemos dažnio pokyčiams. Pastaruoju metu dvigubo maitinimo indukciniu generatoriumi paremtose vejjo turbinose buvo įrengti virtualūs inercijos valdikliai, kad padidintų energetikos sistemos dažnio stabilumą. Tačiau tradiciniai virtualūs inercijos valdikliai, turintys fiksuotą stiprinimo koeficientą, daro neigiamą poveikị regionų tinklų tarpsisteminiams dažnio svyravimams. Siekiant išspręsti šį trūkumą, straipsnyje pateikiami nauji adaptyvūs virtualūs inercijos valdikliai, kurie sumažintų tarpsisteminius svyravimus ir pagerintų dažnio stabilumą. Siūlomoje schemoje virtualių inercijos valdiklių stiprinimo koeficientas yra dinamiškai sureguliuojamas naudojant miglotąją logiką (angl. fuzzy logic). Adaptyvių neraiškių (angl. fuzzy) virtualių inercijos valdiklių efektyvumas ir valdymas vertinami pagal skirtingus dažnio pokyčių įvykius, pavyzdžiui, elektros generacijos netekimą ir trumpojo jungimo trikdžius su apkrovos atjungimu. Modeliavimas atliekamas su dvigubo maitinimo indukciniu generatoriumi paremtomis vejjo jejgainèmis, integruotomis ị bendrą dviejų zonų tinklą, o lyginamieji rezultatai pateikiami trims atvejams: dvigubo maitinimo indukciniam generatoriui be virtualių inercijos valdiklių, dvigubo maitinimo indukciniam generatoriui su fiksuoto stiprinimo koeficiento virtualiu inercijos valdikliu ir dvigubo maitinimo indukciniam generatoriui su adaptyviu neraiškiu virtualiu inercijos valdikliu. Tyrimo rezultatai patvirtina siūlomo adaptyvaus neraiškaus virtualaus inercijos valdiklio gebejimą gerinti tiek tarpsisteminius svyravimus, tiek sistemos dažnio stabilumą.

Raktažodžiai: adaptyvus virtualus inercijos valdiklis, dvigubai maitinamas indukcinis generatorius, dažnio stabilumas, tarpsisteminiai svyravimai, maksimalios galios taško stebejjimas, vejjo turbinos generatorius 